P. G. Rodhouse · U. Piatkowski

\title{
Fine-scale distribution of juvenile cephalopods in the Scotia Sea and adaptive allometry of the brachial crown
}

Received: 17 May 1994/Accepted: 16 June 1995

\begin{abstract}
The pelagic nekton community was sampled with the RMT 25 opening/closing net and a neuston net at two stations in the Scotia Sea south of the Antarctic Polar Front in the open ocean (Station 1) and on the South Georgia northwestern slope (Station 2). Downward oblique tows were made with the RMT 25 through discrete $200 \mathrm{~m}$ layers to $1000 \mathrm{~m}$ in daylight and darkness. A total of 119 cephalopods representing nine species were removed from the samples, and mantle and arm lengths were measured to the nearest $0.1 \mathrm{~mm}$. The most abundant species at each station was an undescribed Brachioteuthis sp. (B. ?picta). Galiteuthis glacialis and Alluroteuthis antarcticus were caught at both stations. Histioteuthis eltaninae, Bathyteuthis abyssicola and Psychroteuthis glacialis were caught at Station 1. Mastigoteuthis psychrophila and a Chiroteuthis sp. were caught at Station 2. B. ?picta was present throughout the water column to $1000 \mathrm{~m}$ at both stations, with little evidence of ontogenetic descent. There was evidence for ontogenetic descent in $G$. glacialis. This species was absent from the Antarctic Surface Water (ASW) at Station 1, where it was concentrated in the Circumpolar Deep Water (CDW). At Station 2 it was present throughout the water column to $1000 \mathrm{~m}$. The other species were all caught in the core of the CDW (>400 m). In juvenile B. ?picta, G. glacialis and $A$. antarcticus, growth of the brachial crown is positively allometric with respect to mantle length. Recent data on biomass spectra in high-latitude pelagic systems show that they are characterised by the presence of peaks of biomass separated by biomass minima.
\end{abstract}

Communicated by J. Mauchline, Oban

P.G. Rodhouse ( $\square)$

British Antarctic Survey, Natural Environment

Research Council, High Cross, Madingley Road,

Cambridge CB3 OET, England

U. Piatkowski

Institut für Meereskunde, Universität Kiel,

Düsternbrooker Weg 20, D-24105 Kiel, Germany
Positive allometric growth in the brachial crown of these antarctic oceanic squid is suggested to have evolved as an adaptation to the peaked, or domed, structure of the pelagic biomass spectrum which must be spanned by these predators as their optimum prey size increases with growth. Interspecific differences in the allometry of tentacle growth are probably related to differences in strategies for stalking and capture of prey.

\section{Introduction}

Cephalopods, especially pelagic squid, caught by antarctic vertebrate predators have been the subject of several studies over the last decade (Clarke 1980; Offredo et al. 1985; Rodhouse et al. 1987, 1990, 1992a; Imber 1992; Rodhouse and Prince 1993) but there are fewer studies based on net-caught specimens, largely because of the relative inefficiency of nets for sampling squid. Information on the fine- and meso-scale distribution of antarctic pelagic cephalopods, and their role as predators in the southern ocean pelagic ecosystem is thus relatively poorly known.

Sampling with the rectangular midwater trawl (RMT) 8 net has shown that the antarctic cranchiids Galiteuthis glacialis and Mesonychoteuthis hamiltoni are concentrated in the upper layer of the Circumpolar Deep Water (CDW) (Rodhouse and Clarke 1985, 1986), but this net is relatively inefficient for catching active muscular cephalopods. In order to sample the muscular cephalopods in the Scotia Sea area, the larger RMT 25 net was deployed in 1987 (Rodhouse 1990) and in 1991 as part of a programme to investigate the community structure and biomass spectrum of the pelagic nekton fauna (Paitkowski et al. 1994; Rodhouse et al. 1994).

Biomass spectra in pelagic systems are characterised by the presence of peaks of biomass separated by biomass minima (Witek and Krajewska-Soltys 1989; 
Boudreau and Dickie 1992) and these minima must be spanned by predators as they grow and the optimum size of their prey increases. Individual body mass at peaks in the biomass spectra are separated by one to several orders of magnitude, so there must be critical periods during the life history of pelagic predators at the point when they are shifting diet from one peak to the next. In this paper we present results on the vertical distribution of cephalopods caught with the RMT 25 and neuston net in 1991 at two stations in the Scotia Sea, and propose the causal hypothesis that strong positive allometric growth in the brachial crown (length of the arms) of three species of squid has evolved as an adaptation to the structure of the pelagic biomass spectrum.

\section{Materials and methods}

Cephalopod specimens were removed from nekton samples taken at two stations occupied by R.R.S. "John Biscoe" south of the Antaretic Polar Front (APF) in the Scotia Sea using an opening/closing rectangular midwater trawl with a design aperture of $25 \mathrm{~m}^{2}$ (RMT 25) (Piatkowski et al. 1994; Rodhouse et al. 1994). At Station 1 (13 to 15 January 1991, oceanic Scotia Sea, bottom depth $4100 \mathrm{~m}$ ), hauls fell within $57^{\circ} 03.8^{\prime} \mathrm{S}$ to $57^{\circ} 08.7^{\prime} \mathrm{S}, 55^{\circ} 08.6^{\prime} \mathrm{W}$ to $55^{\circ} 25.9^{\prime} \mathrm{W}$, and at Station 2 (28 to 30 January 1991, South Georgia northwestern slope, bottom depth $1500 \mathrm{~m}$ ), hauls fell within $53^{\circ} 22.5^{\prime} \mathrm{S}$ to $53^{\circ} 39.1^{\prime} \mathrm{S}$, $38^{\circ} 31.9^{\prime} \mathrm{W}$ to $38^{\circ} 55.7^{\prime} \mathrm{W}$. Each $200 \mathrm{~m}$ layer from the surface to $1000 \mathrm{~m}$ was sampled by nominal $2 \mathrm{~h}$ downward oblique tows in daylight and darkness (defined by sunrise and sunset). Mean water volume filtered per $2 \mathrm{~h}$ haul was $260000 \pm 48000 \mathrm{~m}^{3}$. At each station, a neuston net, a rectangular frame net with a design aperture of $1 \mathrm{~m}^{2}$ and a mesh size of $5 \mathrm{~mm}$, was also deployed in the surface layer from the foredeck. Station positions and vertical hydrographic structure at each station are shown in Fig. 1. The hydrography is described in detail in Piatkowski et al. (1994).

Dorsal mantle length (ML) and arm lengths, from the oral side of the most proximal sucker to the arm tip (ALI-ALIV), of all cephalopods were measured with Vernier calipers to $0.1 \mathrm{~mm}$. Statistical procedures were performed using the Minitab statistical package (Ryan et al. 1985).

\section{Results}

Species

A total of 119 cephalopods were caught. Eight species were identified, together with a further specimen that was unidentifiable. Species depth-range and size data are given in Table 1 .

The most abundant species at each station was an undescribed member of the genus Brachioteuthis. The family Brachioteuthidae is in need of revision (Roper 1983). The Antarctic species has been provisionally identified as B. picta (Roper et al. 1985), but according to Nesis (1987), who refers to it as the notalianAntarctic " $B$. riise $i$ ", this is almost certainly a new species. Here we record it as Brachioteuthis ?picta, which is consistent with previous references to the same species (Rodhouse 1990; Rodhouse et al. 1992a; Piatkowski et al. 1994).

The cranchiid Galiteuthis glacialis and the neoteuthid Alluroteuthis antarcticus were caught at both stations. The psychroteuthid Psychroteuthis glacialis and single specimens of the histioteuthid Histioteuthis eltaninae and bathyteuthid Bathyteuthis abyssicola were caught at Station 1. The mastigoteuthid Mastigoteuthis psychrophila and a single specimen of a Chiroteuthis sp. were caught at Station 2.

\section{Vertical distribution}

Vertical distribution as a function of mantle length in Brachioteuthis ?picta and Galiteuthis glacialis is shown in Fig. 2. B. ?picta was present throughout the water column to $1000 \mathrm{~m}$, and there was little evidence of ontogenetic descent. The two largest specimens (83 and $113 \mathrm{~mm} \mathrm{ML}$ ) were caught at the surface in the foredeck frame net with the RMT25 at 800 to $1000 \mathrm{~m}$. No $B$. ?picta were caught in the 0 to $200 \mathrm{~m}$ layer in daylight, which may reflect either a diel vertical migration pattern or avoidance of the nets in daylight. Largest numbers were caught at 400 to $800 \mathrm{~m}$ in the core of the CDW.

There was some evidence for ontogenetic descent in Galiteuthis glacialis, with the largest specimens ( $>140 \mathrm{~mm}$ ML) being caught in the 800 to $1000 \mathrm{~m}$ layer. The species was absent from the Antarctic Surface Water (ASW) at Station 1, where it was concentrated in the CDW. At Station 2 it was present throughout the water column to $1000 \mathrm{~m}$.

The other six species were all caught at depths $>400 \mathrm{~m}$ in the core of the CDW.

\section{Allometry}

Allometric constants for the equations relating mantle length to arm and tentacle length in Brachioteuthis ?picta, Galiteuthis glacialis and Alluroteuthis antarcticus are given in Table 2. In those species for which a sufficient size range of specimens is available for analysis, growth of all arms is positively allometric with respect to mantle length $(b>1.0 ; p<0.05)$. The arms grow at a relatively faster rate than the mantle, so that in $B$. ?picta, G. glacialis and $A$. antarcticus mean arm length, as a proportion of mantle length, increases from 0.20 to $0.34,0.07$ to 0.18 and 0.40 to 0.62 respectively between 15 and $50 \mathrm{~mm} \mathrm{ML}$. The intercepts $(A)$ in the equations in Table 2 show that $A$. antarcticus has the longest arms, and hence largest brachial crown, relative to mantle length, and $G$. glacialis has the smallest. $B$. ?picta is intermediate in this respect. Furthermore, in $A$. antarcticus in which the brachial crown is large relative to mantle length, allometric growth is least pronounced, and in G. glacialis, which has a relatively 


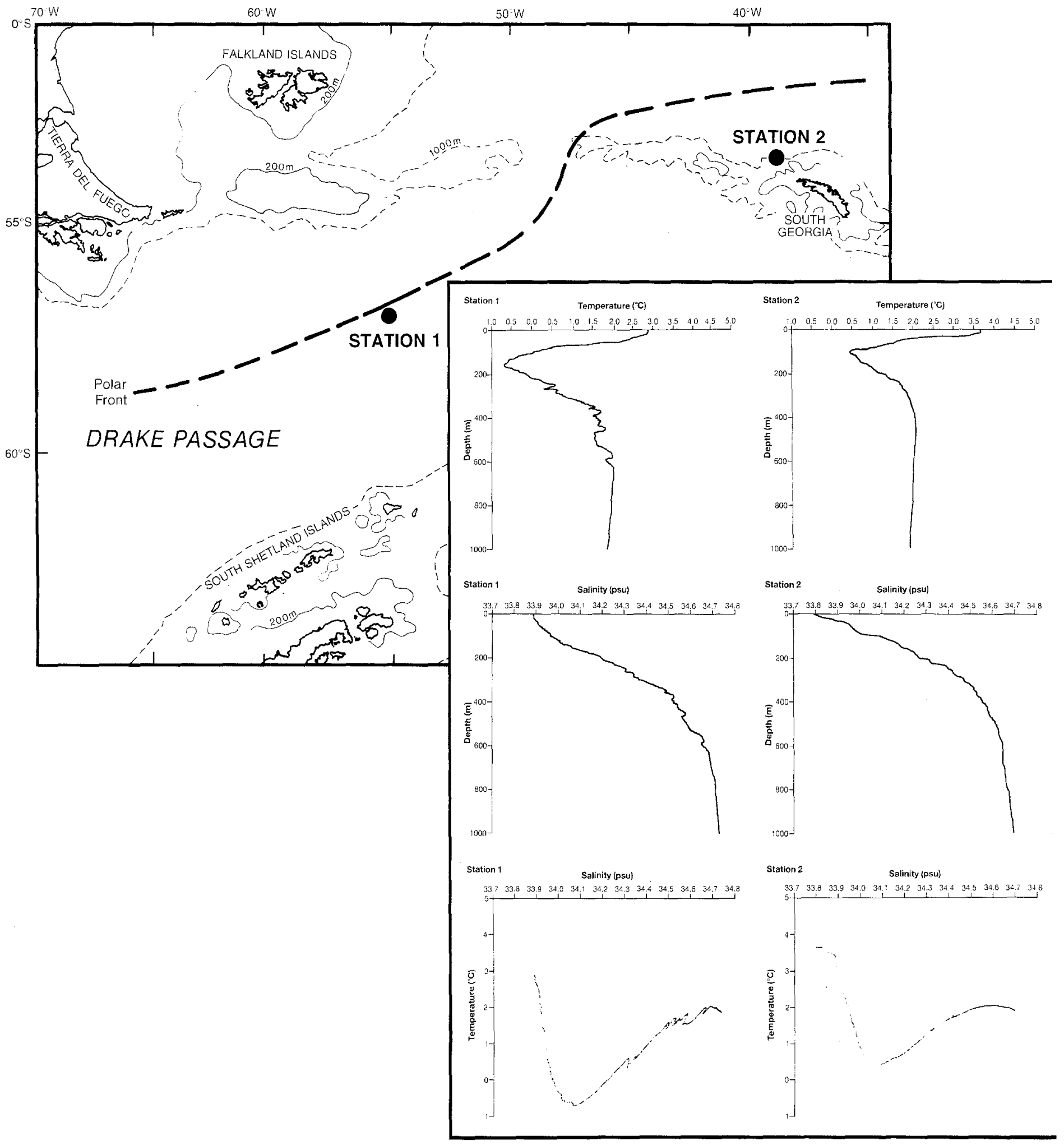

Fig. 1 Atlantic sector of southern ocean, showing positions of Stations 1 and 2 in relation to Polar Front and South Georgia (Inset hydrographic profiles and temperature/salinity diagrams at each station)

small brachial crown, allometric growth is most strongly positive. B. ?picta is similarly intermediate.
In Brachioteuthis ?picta tentacle growth is isometric with respect to mantle length $(b=\sim 1.0 ; p>0.05)$, in Galiteuthis glacialis tentacle growth is negatively allometric with mantle length $(b<1.0 ; p<0.05)$, and in Alluroteuthis antarcticus tentacle growth is positively allometric with mantle length $(b>1.0 ; p<0.05)$ (Table 2). A. antarcticus has the shortest tentacles in 
Table 1 Cephalopod species, numbers, depth range and mantle lengths sampled with RMT25 at two stations in Scotia Sea (- no data)

\begin{tabular}{|c|c|c|c|c|c|c|}
\hline \multirow[t]{2}{*}{ Species } & \multicolumn{3}{|l|}{ Station 1} & \multicolumn{3}{|l|}{ Station 2} \\
\hline & $\begin{array}{l}\text { Depth range } \\
(\mathrm{m})\end{array}$ & $\begin{array}{l}\text { Mantle length } \\
\text { range (mm) }\end{array}$ & $(N)$ & $\begin{array}{l}\text { Depth range } \\
\text { (m) }\end{array}$ & $\begin{array}{l}\text { Mantle length } \\
\text { range }(\mathrm{mm})\end{array}$ & $(N)$ \\
\hline Brachioteuthis ?picta & $0-1000$ & $15-77$ & (21) & $0-1000$ & $27-113$ & (53) \\
\hline Galiteuthis glacialis & $400-1000$ & $10-61$ & (16) & $200-1000$ & $9-186$ & (9) \\
\hline Alluroteuthis antarcticus & $600-1000$ & $16-52$ & (6) & $800-1000$ & 44 & (1) \\
\hline Mastigoteuthis psychrophila & - & - & & $400-1000$ & $74-122$ & (7) \\
\hline Chiroteuthis sp. & - & - & & $800-1000$ & 91 & (1) \\
\hline Histioteuthis eltaninae & $400-600$ & 70 & (1) & - & 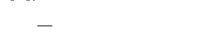 & \\
\hline Bathyteuthis abyssicola & $800-1000$ & 63 & (1) & - & - & \\
\hline Psychroteuthis glacialis & $0-800$ & $6-14$ & (2) & - & - & \\
\hline Unidentifiable & - & - & & $400-600$ & 11 & (1) \\
\hline Total & & & (47) & & & $(72)$ \\
\hline
\end{tabular}

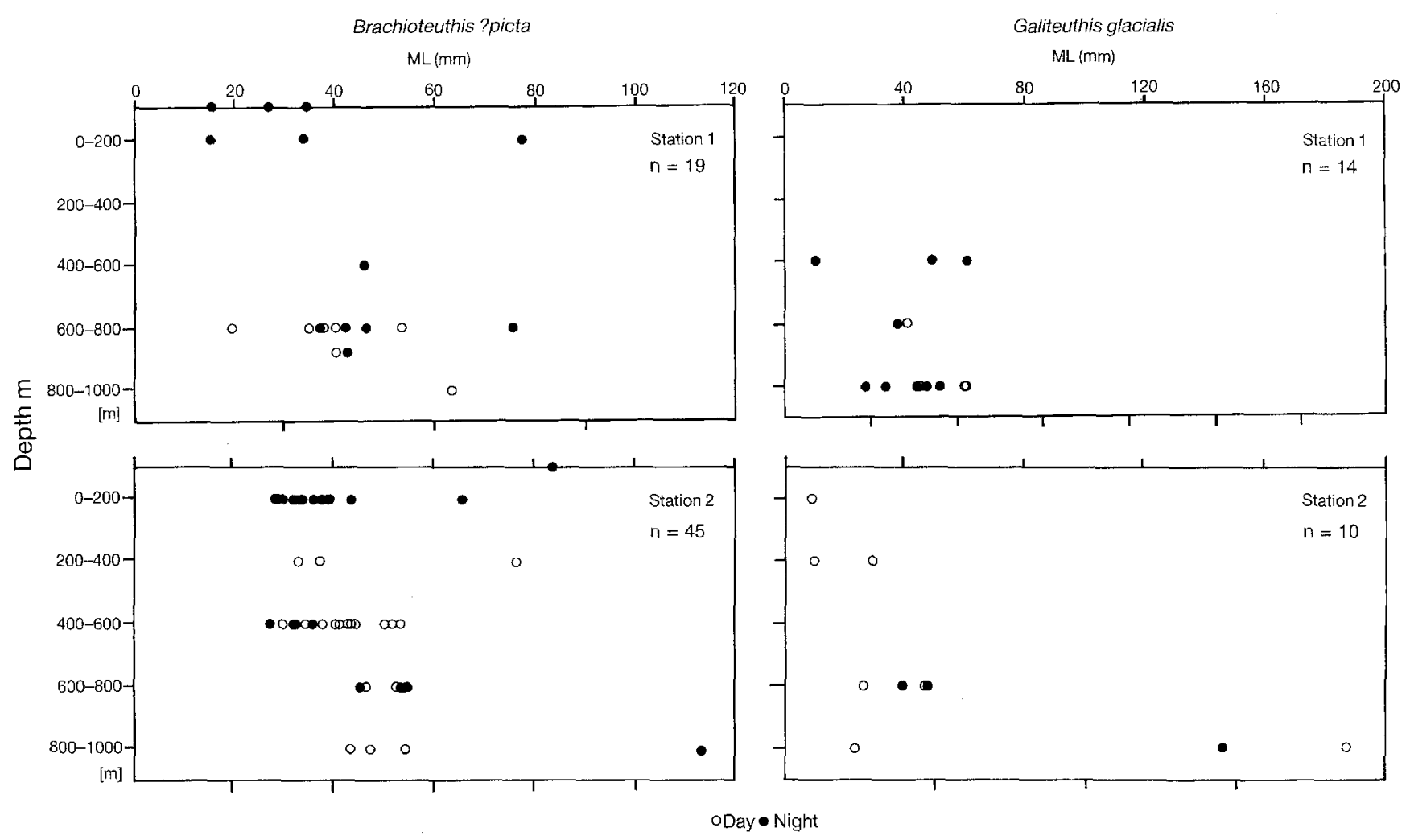

Fig. 2 Brachioteuthis ?picta and Galiteuthis glacialis. Vertical distribution in daylight and darkness as a function of mantle length

relation to ML, G. glacialis the longest, and B. ?picta is intermediate in this respect.

\section{Discussion}

\section{Distribution}

This study arises from the second of two cruises in which the RMT 25 has been used to sample cephalopods in the Scotia sea. The species composition was largely similar to that sampled with the same net fished open at two stations in the vicinity of South Georgia in 1987 (Rodhouse 1990). However, Gonatus antarcticus, Kondakovia longimana, Batoteuthis skolops, Taonius sp., and a pelagic octopodid which were present in small numbers in the 1987 samples, were absent from the present collection. Several Antarctic species that are frequent in the diet of vertebrate predators at South Georgia (Rodhouse et al. 1987, 1990, 1992a; Rodhouse and Prince 1993) were not caught with this net. The most conspicuously absent were Martialia hyadesi, Kondakovia longimana and Moroteuthis knipovitchi, which are among the most important prey species in terms of biomass and number. 
Table 2 Brachioteuthis ?picta, Galiteuthis glacialis and Alluroteuthis antarcticus. Allometric constants $A$ and $b$ for relationship between arm length $(A L) \mathrm{I}-\mathrm{IV}$, tentacle length $(T t L)$ and mantle length $(M L)$ $\left(\ln A L=\mathrm{A}+\ln M L^{b} ; \ln T t L=\mathrm{A}+\ln M L^{b}\right)$

\begin{tabular}{lllll}
\hline & \multicolumn{1}{c}{$A$} & $b$ & $r^{2}$ & $(d f)$ \\
\hline Brachioteuthis ?picta & & & & \\
AI & -4.82 & 1.89 & 0.891 & $(73)$ \\
AII & -2.35 & 1.39 & 0.845 & $(75)$ \\
AIII & -2.78 & 1.49 & 0.813 & $(75)$ \\
AIV & -3.93 & 1.73 & 0.840 & $(74)$ \\
TtL & -0.93 & 1.21 & 0.708 & $(54)$ \\
Galiteuthis glacialis & & & & \\
AI & -5.13 & 1.77 & 0.912 & $(25)$ \\
AII & -4.25 & 1.64 & 0.907 & $(25)$ \\
AIII & -3.93 & 1.61 & 0.878 & $(25)$ \\
AIV & -4.99 & 1.86 & 0.811 & $(24)$ \\
TtL & 0.25 & 0.86 & 0.888 & $(24)$ \\
Alluroteuthis antarcticus & & & & \\
AI & -2.10 & 1.38 & 0.884 & $(5)$ \\
AII & -1.62 & 1.30 & 0.897 & $(5)$ \\
AIII & -2.15 & 1.46 & 0.978 & $(5)$ \\
AIV & -2.54 & 1.53 & 0.899 & $(5)$ \\
TtL & -3.11 & 1.97 & 0.995 & $(2)$ \\
\hline
\end{tabular}

The presence of comparatively large numbers of juvenile Brachioteuthis ?picta, Galiteuthis glacialis and Alluroteuthis antarcticus at the offshore Station 1 indicates that these species are all oceanic spawners that breed in the Antarctic Circumpolar Current and are likely to have uninterrupted circumpolar distributions. Paralarvae and juveniles of two species, Martialia hyadesi and Gonatus antarcticus, that are common in the diet of predators in the Scotia Sea, have been caught on the southern edge of the Patagonian Shelf (Rodhouse et al. 1992b), indicating that spawning takes place on the shelf edge or shelf break region. The spawning areas of other species, known from predator data to be abundant in the region, remain to be established. Furthermore, the presence of undescribed species of the genera Brachioteuthis and a new species of Chiroteuthis in the present collection emphasises the need for systematics research on the southern ocean cephalopods. Both the Brachioteuthidae and the Chiroteuthidae are in need of revision (Roper 1983).

Apart from Brachioteuthis ?picta, all cephalopod species caught during this study were associated with the upper and lower mesopelagic nekton communities of the CDW described by Piatkowski et al. (1994). The vertical distribution of $B$. ?picta extended into the epipelagic community of the ASW. This species was caught in the top $1 \mathrm{~m}$ of the ocean in the neuston net, and so it is difficult to explain its absence from the diet of near-surface feeding seabirds (Rodhouse et al: 1987, 1990; Rodhouse and Prince 1993), although it occurs frequently in the gut contents of the deep-diving southern elephant seal (Rodhouse et al. 1992a). Conversely it remains paradoxical that species such as Galiteuthis glacialis and Alluroteuthis antarcticus, large specimens of which have only been caught by nets in the mesopelagic zone, are regularly found in the gut contents of near-surface feeding seabirds. It has been suggested that these species float when dead or moribund, which may explain their presence in the diet of surface and near-surface feeding birds (Lipinski and Jackson 1989).

\section{Adaptive allometry}

The RMT 25 net that caught the cephalopods in this study apparently sampled the smaller organisms comprising the left-hand side of a peak in the biomass spectrum including nektonic crustaceans, fishes and the gelatinous cnidarians, ctenophores and tunicates with body volumes in the range 0.1 to $100 \mathrm{~cm}^{3}$ (Rodhouse et al. 1994). The spectrum of smaller planktonic and microplanktonic organisms in the Antarctic pelagic system was analysed by Witek and Krajewska-Soltys (1989) in spring/summer and was found to be characterised by peaks dominated by phytoplankton and ciliates, cyclopoid copepods, calanoid copepods, chaetognaths, small euphausiids and salps. The peak composed of cyclopoid copepods corresponded to body volumes in the range $2 \times 10^{6}$ to $3 \times 10^{7} \mu^{3}$, that comprised of calanoid copepods and chaetognaths corresponded to body volumes in the range 1 to $50 \mathrm{~mm}^{3}$, and that comprised of salps corresponded to body volumes in the range 1 to $10 \mathrm{~cm}^{3}$. A peak composed of large euphausiids fell in a body-volume class intermediate between calanoid copepods etc. and salps.

The presence of peaks within the pelagic biomass spectrum provides the basis for a causal hypothesis to explain the evolution of strongly positive allometric growth in the brachial crown of juvenile oceanic squids such as Brachioteuthis ?picta, Galiteuthis glacialis and Alluroteuthis antarcticus reported here and for other species reported elsewhere (Vidal 1994). The hypothesis is as follows: the squids generally grow rapidly relative to other members of the nekton, usually reaching full adult size in $\simeq 1$ yr. The brachial crown - the squid's functional mouth (Packard 1972), is relatively small at hatching, and adapted for predation on the smallest metazoan peak in the pelagic biomass spectrum occupied by cyclopoid copepods. As the squids rapidly grow and enter the juvenile phase, they track across the biomass spectrum and shift the diet from the small planktonic peaks to the larger nektonic peaks of biomass occupied by the euphausiids and myctophid fishes. It is in response to this need to shift predation from one peak in the biomass spectrum to the next that the relative size of the brachial crown changes rapidly, accommodating the transition between diets differing in individual body volume by approximately one order of magnitude. This concept of adaptive positive allometry of brachial crown growth in response to the peaked pelagic biomass spectrum is illustrated in Fig. 3 using G. glacialis as an example. 


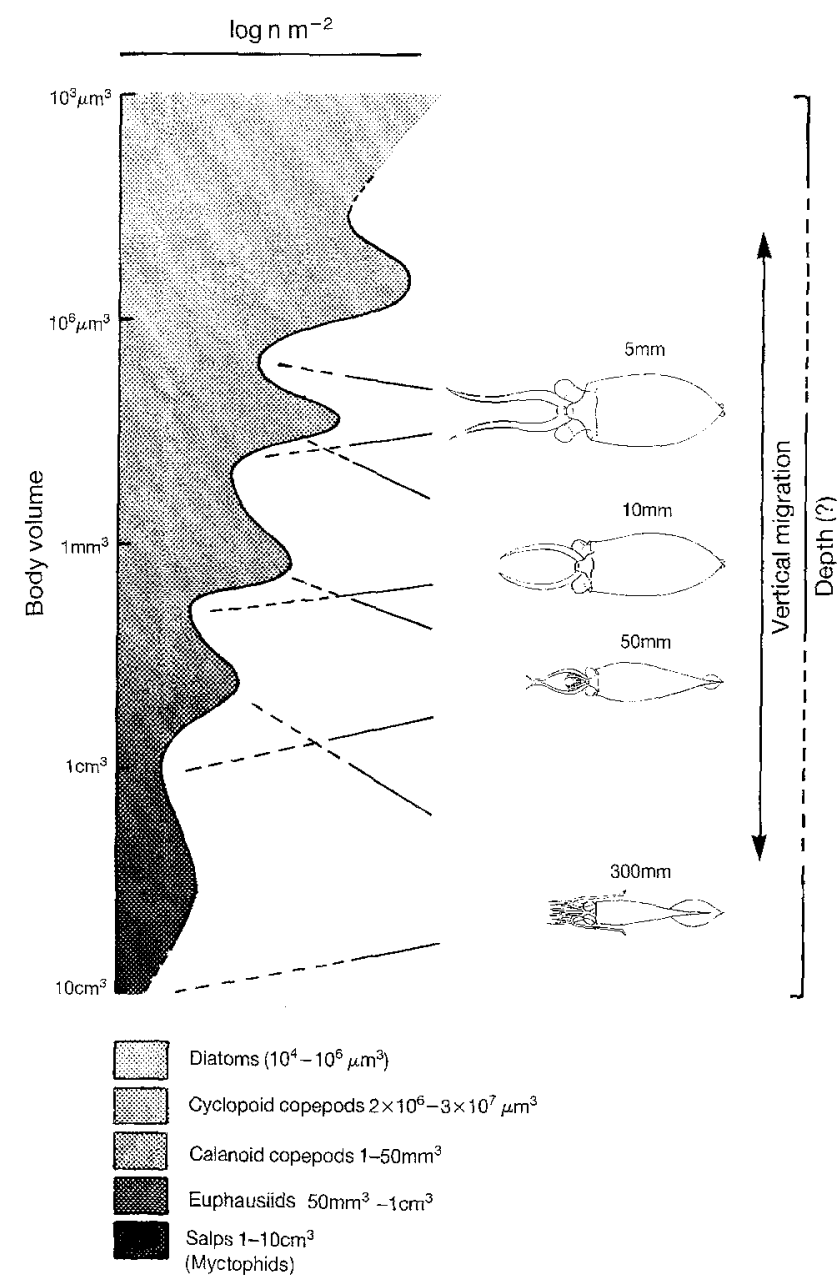

Fig. 3 Galiteuthis glacialis. Schematic diagram illustrating concept of adaptive allometry of brachial crown in response to antarctic pelagic biomass spectrum. Mantle lengths are drawn the same size in order to emphasise positive allometric growth of brachial crown (note logarithmic biomass-spectrum scale)

In common with arm growth, tentacle growth with respect to mantle length is positively allometric in $\mathrm{Al}$ luroteuthis antarcticus but negatively allometric in Galiteuthis glacialis, and isometric in Brachioteuthis ?picta. According to the causal hypothesis, the allometry of the brachial crown shows the same response to the domed structure of the biomass spectrum, and the need to shift predation between domes, in all three species but, on the evidence of relative growth of the tentacle, the development of strategies for stalking and capture of prey differs among these species.

Inter-specific differences in the size of the brachial crown relative to body size, together with the relative size and form of the armature of the arms and tentacles, hatching depth and rate of ontogenetic descent, may additionally provide a mechanism for trophic niche separation among sympatric species of pelagic cephalopods (Rodhouse 1988).

We can speculate that the short life cycles of pelagic squid coupled with high levels of intra-specific variabil- ity in characters such as arm and tentacle length might give rise to rapid and reversible microevolutionary changes in the brachial crown within populations. In response to inter-annual variability in the shape of the pelagic biomass spectrum, selection may favour certain allometric variations. If such microevolutionary events occur, this would explain some of the temporal and geographical variability of species, and limit the value of squid morphometrics as taxonomic characters.

Acknowledgements We thank the officers and crew of the R.R.S. "John Biscoe" and the British Antarctic Survey scientists participating in Cruise JB11 for their help on deck and in the ship's laboratory. The second author's participation in the cruise was supported by the Deutsche Forschungsgemeinschaft and the British Antarctic Survey. This paper was written while the authors were in receipt of grants under the British-German Academic Research Collaboration programme of the British Council and the Deutscher Akademischer Austauschdienst (AT 313-ARC-VI-92/65).

\section{References}

Boudreau PR, Dickie LM (1992) Biomass spectra of aquatic ecosystems in relation to fisheries yield. Can J Fish aquat Sciences 49: $1528-1538$

Clarke MR (1980) Cephalopods in the diet of sperm whales of the southern hemisphere and their bearing on sperm whale biology. 'Discovery' Rep 37: 1-324

Imber MJ (1992) Cephalopods eaten by wandering albatrosses (Diomedea exulans L.) breeding at six circumpolar localities. $\mathrm{Jl}$ R Soc NZ 22: 243-263

Lipinski MR, Jackson S (1989) Surface-feeding on cephalopods by procellariiform seabirds in the Southern Benguela region, South Africa. J Zool, Lond 218: 549-563

Nesis KN (1987) Cephalopods of the world. T.F.H. Publications Inc., Neptune City, New Jersey

Offredo C, Ridoux V, Clarke MR (1985) Cephalopods in the diet of Emperor and Adelie penguins in Adelie Land, Antarctica. Mar Biol 86: 199-202

Packard A (1972) Cephalopods and fish: the limits of convergence. Biol Rev 47: 241-307

Piatkowski U, Rodhouse PG, Murphy EJ, White MG, Bone DG (1994) Nekton community of the Scotia Sea as sampled by the RMT 25 during austral summer. Mar Ecol Prog Ser 112: 13-28

Rodhouse PG (1988) Distribution of the neoteuthid squid Alluroteuthis antarcticus Odhner in the Atlantic sector of the Southern Ocean. Malacologia 29: 267-274

Rodhouse PG (1990) Cephalopod fauna of the Scotia Sea at South Georgia: potential for commercial exploitation and possible consequences. In: Kerry K. Hempel $G$ (eds) Ecological change and the conservation of Antarctic ecosystems. Proceedings of the 5th SCAR Symposium on Antarctic Biology. Springer-Verlag, Berlin, pp 289-298

Rodhouse PG, Ambom TR, Fedak MA, Yeatman J, Murray AWA (1992a) Cephalopod prey of the southern elephant seal, Mirounga leonina L. Can J Zool 70: 1007-1015

Rodhouse PG, Clarke MR (1985) Growth and distribution of young Mesonychoteuthis hamiltoni Robson (Mollusca: Cephalopods): an Antarctic squid. Vie Milieu 35: 223-230

Rodhouse PG, Clarke MR (1986) Distribution of the early-life phase of the Antarctic squid Galiteuthis glacialis in relation to the hydrology of the Southern Ocean in the sector $15^{\circ}$ to $30^{\circ} \mathrm{E}$. Mar Biol 91: 353-357

Rodhouse PG, Clarke MR, Murray AWA (9187) Cephalopod prey of the wandering albatross Diomedea exulans. Mar. Biol 96: 1-10 
Rodhouse PG, Piatkowski U, Murphy EJ, White MG, Bone DG (1994) Utility and limits of biomass spectra: the nekton community sampled with the RMT 25 in the Scotia Sea during austral summer. Mar Ecol Prog Ser 112: 29--39

Rodhouse PG, Prince PA (1993) Cephalopod prey of the blackbrowed albatross Diomedea melanophrys at South Georgia. Polar Biol 13: 373-376

Rodhouse PG, Prince PA, Clarke MR, Murray AWA (1990) Cephalopod prey of the grey-headed albatross Diomedea chrysostoma. Mar Biol 104: 353-362

Rodhouse PG, Symon C, Hatfield EMC (1992b) Early life cycle of cephalopods in relation to the major oceanographic features of the southwest Atlantic. Mar Ecol Prog Ser 89: 183-195

Roper CFE (1983) An overview of cephalopod systematics: status, problems and recommendations Mem natn Mus Vict 44: 13-27
Roper CFE, Sweeney MJ, Clarke MR (1985) Cephalopods. In: Fischer W, Hureau JC (eds). FAO species identification sheets for fishery purposes. Southern Ocean (Fishing areas 48, 58 and 88) (CCAMLR Convention Area). Vol. I. Prepared and published with the support of the Commission for the Conservation of Antarctic Living Marine Resources. FAO, Rome, pp 117-205

Ryan BF, Joiner BL, Thomas A, Ryan Jr TA (1985) Minitab handbook. 2nd edn. Duxbury Press, Boston, Mass

Vidal EAG (1994) Relative growth of paralarvae and juveniles of Illex argentinus (Castellanos, 1960) in Southern Brazil. Antarct Sci 6: 275-282

Witek Z, Krajewska-Soltys A (1989) Some examples of the epipelagic plankton size structure in high latitude oceans. J Plankton Res 11: 1143-1155 